\title{
Peningkatan Keterampilan Berbicara Melalui Proses Penerapan Metode Bermain Peran Siswa Kelas IV SDNegeri 03 Merigi Semester I Tahun 2015/2016
}

\section{Latifah}

SD Negeri 03 Merigi

latifahtifah689@yahoo.com

\begin{abstract}
This research attempted to study the problem of (1) How to improve the skill of $V$ grade students of Primary School 03 Merigi Regency Kepahiang school year 2015/2016 in learning ability of speaking, and (2) How to change the behavior of fourth grade students Primary School 03 Years of Kepahiang Regency year teaching 2015/2016 in learning to speak after being given a learning by applying a role playing method.The purpose of this study is to describe the effort to improve the speaking skill and behavioral change of class IV students of Primary School O3 Merigi District Kepahiang Regency by learning to talk about application of role playing method. The variables in this study are the variables of improving the students' speaking skills. Data collection at the preliminary stage uses test techniques, while data collection at cycle 1 and cycle II uses test and nontes techniques. The results of the study were analyzed by quantitative and qualitative techniques.The result of this study shows that after the learning - learning method, the application of the class role of the fourth - grade class student of the Primary School of Primary School 03 Merigi Kepahiang Regency from the value of cycle I to cycle II up to cycle III increased. From the implementation of each cycle, the value is 41.35 in cycle I, and 62.65 in cycle II then 76.5 in cycle III. Improving student-speaking skills is also followed by changes in behavior and interest and student activity. From the results of the student-speaking skill study, it can be concluded that the ability of fourth grade elementary school students 03 Merigi District of Kepahiang Regency improved after following the learning process talking with the application of role playing method.
\end{abstract}

Keywords: Role play method improves speaking skill

\section{Pendahuluan}

Berbicara merupakan salah satu aspek keterampilan berbahasa yang bersifat produktif, artinya suatu kemampuan yang dimiliki seseorang untuk menyampaikan gagasan, pikiran atau perasaan sehingga gagasan-gagasan yang ada dalam pikiran pembicara dapat dipahami orang lain. Berbicara berarti mengemukakan ide atau pesan lisan secara aktif melalui lambang-lambang bunyi agar terjadi kegiatan komunikasi antara penutur dan mitra tutur. Memang setiap orang dikodratkan untuk bisa berbicara atau berkomunikasi secara lisan, tetapi tidak semua memiliki keterampilan untuk berbicara secara baik dan benar. Oleh karena itu, pelajaran 
berbicara seharusnya mendapat perhatian dalam pengajaran keterampilan berbahasa di Sekolah Dasar.

Kemampuan berpikir tersebut akan terlatih ketika mereka mengorganisasikan, mengonsepkan, dan menyederhanakan pikiran, perasaan, dan ide kepada orang lain secara lisan.Dengan kata lain, dalam kehidupan sehari-hari siswa selalu melakukan dan dihadapkan pada kegiatan berbicara. Siswa yang tidak terampil berbicara dengan baik dan benar, akan mengalami kesulitan dalam mengikuti kegiatan pembelajaran untuk semua mata pelajaran. Menurut Santrock (2012, p.252) penggunaan dialog sebagai alat scaffolding merupakan salah satu contoh penting peran bahasa di dalam perkembangan anak. Namun, pada kenyataannya pembelajaran berbicara di sekolah-sekolah belum bisa dikatakan maksimal, sehingga keterampilan siswa dalam berbicara pun masih rendah.Permasalahan dalam kemampuan berbicara juga terjadi pada siswa kelas IV SD Negeri 03 Merigi Kabupaten Kepahiang Propinsi Bengkulu. Hal ini dapat diketahui berdasarkan hasil dari dua kali tugas berbicara siswa pada semester 1. Dari data yang ada menunjukkan bahwa pada tes tersebut hanya sebagian kecil siswa (2 orang siswa) atau sekitar $10 \%$ yang mendapat nilai 70 ke atas (KKM), sedangkan sisanya (90\%) atau sebanyak 18 siswa mendapat nilai di bawah 60. Selain itu, dari tugas pertama dan kedua tidak menampakkan adanya peningkatan kemampuan berbicara siswa.

Adapun penyebab rendahnya kemampuan berbicara siswa, yakni sebagai berikut: (1) Sikap dan minat siswa dalam mengikuti pembelajaran berbicara rendah. Pada umumnya siswa merasa takut dan malu saat ditugasi untuktampil berbicara di depan teman-temannya. (2) Siswa kurang terampil sebagai akibat dari kurangnya latihan berbicara. (3) Pembelajaran berbicara yang dilakukan masih sederhana atau konvensional karena masih bertumpu pada buku pelajaran. Metode pembelajaran berbicara yang sering digunakan adalah metode penugasan secara individu sehingga banyak menyita waktu pembelajaran Bahasa Indonesia yang hanya 5 jam pelajaran dalam satu minggu.

Untuk mengoptimalkan hasil belajar, terutama keterampilan berbicara, diperlukan metode pengajaran yang lebih menekankan pada aktivitas belajar aktif dan kreativitas para siswa selama proses pembelajaran berlangsung. Hal ini diperkuat oleh pendapat Nurhatim (2009) yang mengatakan bahwa penggunaan suatu metode memiliki arti penting sebagai variasi pembelajaran dengan tujuan siswa dapat mengikuti aktivitas pembelajaran di kelas yang menyenangkan dan tidak membosankan. Untuk itu, guru perlu mengubah metode mengajar konvensional dengan penerapan metode bermain peran. Bermain peran merupakan teknik bermain peran secara sederhana. Dalam bermain peran, siswa dibagi untuk memerankan tokoh-tokoh tertentu sesuai dengan tema pelajaran saat itu.

\section{Metode}

Penelitian ini dilakukan selama 3bulan, yaitu mulai dari bulan September 2015 sampai dengan bulan November 2015.Subjek penelitian adalah siswa kelas IV SD Negeri 03 Merigi Kabupaten Kepahiang tahun ajaran 2015/2016, dengan jumlah siswa 20 orang yang terdiri dari 11 siswa perempuan dan 9 siswa laki-laki. Penelitian ini mengambil objek penelitian pembelajaran keterampilan berbicara pada mata pelajaran Bahasa Indonesia.

Penelitian ini berbentuk Penelitian Tindakan Kelas (Classroom Action Research). Hopkins (dalam Rochiati Wiriaatmadja, 2007: 11) menyatakan bahwa penelitian tindakan kelas adalah sebuah penelitian yang mengkombinasikan prosedur penelitian dengan tindakan substantif, atau suatu usaha seseorang untuk 
memahami apa yang sedang terjadi sambil terlibat dalam sebuah proses perbaikan dan perubahan.

Sumber data dalam penelitian ini ada tiga, yaitu:

1. Peristiwa, yaitu kegiatan berbicara yang berlangsung di dalam kelas dengan penerapan metode bermain peran.

2. Informan, dalam penelitian ini menggunakan informan guru dan siswa kelas IV SD Negeri 03 Merigi Kabupaten Kepahiang.

3. Dokumen yang berupa catatan wawancara dengan guru dan siswa mengenai pembelajaran keterampilan berbicara, hasil tes siswa, rancangan pedoman pembelajaran yang dibuat guru, silabus yang ditetapkan oleh pihak sekolah, serta hasil angket yang diisi oleh siswa.

\section{Teknik Pengumpulan Data}

1. Teknik in dept interview (wawancara mendalam).

Wawancara dilakukan untuk menggali informasi guna memperoleh data yang berkenaan dengan aspek permasalahan pembelajaran berbicara, penentuan tindakan, dan respon yang timbul sebagai akibat dari tindakan yang dilakukan.

2. Obsevasi atau pengamatan.

Pengamatan dilakukan sebelum, selama, dan sesudah siklus penelitian berlangsung. Observasi atau pengamatan dilakukan di dalam proses pembelajaran berbicara untuk mengetahui perkembangan pembelajaran berbicara yang dilakukan oleh guru dan siswa . Sedangkan pengamatan terhadap siswa difokuskan pada keaktifan siswa dalam mengikuti proses pembelajaran, minat dan kemampuan siswa dalam melakukan prektek berbicara di depan kelas.

3. Angket.

Teknik pengumpulan data ini dilakukan dengan cara meminta informan untuk menjawab beberapa pertanyaan yang berhubungan dengan penelitian yang dilaksanakan. Angket dalam penelitian ini diterapkan sebanyak dua kali, yaitu pada kondisi pratindakan dan pascatindakan.

4. Tes.

Teknik pengumpulan data berupa penilaian tes praktik berbicara digunakan untuk mengetahui perkembangan atau keberhasilan pelaksanaan tindakan. Di dalam penelitian ini guru memberikan tes berbicara lisan di depan kelas.

Teknik analisis data yang digunakan dalam penelitian ini adalah analisis model interaktif yang merupakan interaksi dari empat komponen, yaitu: (1) pengumpulan data, (2) reduksi, (3) penyajian data (display data) dan, (4) penarikan kesimpulan.

Adapun langkah-langkah analisis model interaktif yang dikembangkan:

1. Pengumpulan data

Selama pengumpulan data peneliti membuat catatan lapangan yang terdiri dari bagian deskripsi, dan refleksinya adalah data yang telah digali dan dicatat. Dalam pengumpulan data ini artinya peneliti mencatat dan merekam segala bentuk interaksi antara guru dan siswa selama proses pembelajaran.

2. Reduksi data

Kegiatan reduksi data berupa penyusunan rumusan pengertian dari deskripsi dan refleksi secara singkat, berupa pokok-pokok temuan yang penting serta menyeleksi data yang kurang mendukung.

3. Sajian data

Data yang sudah terkumpul kemudian dikelompokkan dalam beberapa bagian sesuai dengan jenis permasalahannya supaya makna peristiwanya menjadi lebih jelas dipahami, dengan dilengkapi perabot sajian yang diperlukan (seperti matriks, gambar, dan sebagainya). 


\section{Hasil}

Diketahui bahwa terjadi permasalahan dalam pembelajaran berbicara pada siswa kelas IV SD Negeri 03 Merigi,karena pembelajaran berbicara masih sulit untuk dilakukan secara optimal mengingat rendahnya minat siswa terhadap pelajaran berbicara dan kurangnya penerapan metode pembelajaran berbicara itu sendiri, sehingga berakibat pada rendahnya kemampuan berbicara siswa. Pendapat tersebut juga didukung oleh hasil wawancara dengan beberapa siswa mengenai minat mereka terhadap pelajaran berbicara. Dari empat siswa yang diwawancarai, tiga diantaranya menyatakan kurang berminat terhadap pelajaran berbicara. Pada umumnya mereka menyatakan kurang suka mengikuti pembelajaran berbicara di kelas karena merasa takut, malu dan kesulitan untuk mengungkapkan pikiran dan perasaannya secara lisan di depan kelas ketika dilihat oleh guru dan siswa lain. Pembelajaran berbicara dengan metode bersifat konvensional.Materi pembelajaran berbicara diambil dari buku, kemudian apa yang ada dalam buku tersebut ditugaskan kepada siswa.

Berdasarkan kondisi awal selanjutnya peneliti melakukan diskusi dengan teman sejawat guru untuk mencari solusi permasalahan yang terjadi dalam pembelajaran berbicara, sehingga dicapailah kesepakatan bahwa peneliti akan melakukan penelitian tindakan kelas bersama guru kelas sebagai kolaborator.

Penerapan tindakan ini difokuskan pada peningkatan proses dan hasil pembelajaran berbicara. Melihat penyebab rendahnya kemampuan berbicara yang bersumber dari siswa yaitu pada rendahnya sikap (meliputi minat dan keaktifan), maka peningkatan proses pada penelitian ini lebih memfokuskan pada aspek minat dan keaktifan siswa saja. Sedangkan hasil pembelajaran difokuskan pada peningkatan keterampilan berbicara dan jumlah ketuntasan belajar siswa.

Proses penelitian ini dilakukan dalam tiga siklus yang masing-masing terdiri atas empat tahapan, yaitu: (1) perencanaan tindakan, (2) pelaksanaan tindakan, (3) observasi dan interpretasi, serta (4) analisis dan refleksi.

1. Siklus Pertama (I)

a. Perencanaan Tindakan

Pelaksanaan tindakan siklus I akan dilaksanakan dalam dua kali pertemuan. Dilaksanakan dalam dua kali pertemuan dikarenakan adanya keterbatasan waktu dan hal itu dirasa tidak cukup untuk memenuhi kebutuhan aktivitas pembelajaran dengan metode bermain peran ini. Tahap perencanaan tindakan ini meliputi kegiatan sebagai berikut:

1) Guru merancang skenario pembelajaran berbicara dengan penerapan metode bermain peran, dengan langkah-langkah sebagai berikut: (a) Guru membuka pelajaran dan memberikan apersepsi dengan menggali pengalaman siswa yang berkaitan dengan materi berbicara (melalui tanya jawab seputar pengetahuan siswa tentang jenis kegiatan berbicara). (b) Guru mengawali kegiatan inti dengan memberikan penjelasan tentang materi diskusi. (c) Guru memperdengarkan rekaman percakapan diskusi sambil membagikan transkrip hasil rekaman tersebut. (d) Guru membagi siswa menjadi 4 (empat) kelompok (masing-masing beranggotakan 5 orang). (e) Guru menugasi masing-masing kelompok untuk melakukan diskusi dengan metode bermain peran. (f) Guru dan siswa melakukan tahap persiapan, yaitu: membagikan skenario role play, menentukan peran yang akan dimainkan setiap peserta, menjelaskan skenario, menentukan aturan permainan, dan menjelaskan tujuan pembelajaran. (g) Siswa melakukan role play secara berkelompok. Setiap kelompok diberi waktu 8 menit, dengan rincian 5 menit untuk pemeranan dan 3 menit untuk refleksi dan evaluasi. (h) Guru bersama siswa lain mengamati penampilan kelompok pemain. (i) Di 
setiap akhir penampilan, guru melakukan refleksi dan evaluasi tahap I (yaitu guru bersama siswa pengamat memberikan kritik, masukan, dan komentar). (j) Berdasarkan hasil refleksi dan evaluasi tahap I, guru meminta siswa untuk menampilkan ulang perannya.(k) Guru melakukan refleksi dan evaluasi tahap II diakhir penampilan ulang siswa dan memberikan kesempatan kepada mereka untuk menanyakan hal-hal yang belum dipahami.

2) Guru menutup pelajaran.

3) Guru menyusun Rencana Pelaksanaan Pembelajaran (RPP).

4) Guru dan peneliti mempersiapkan materi dan membuat skenario bermain peran siklus I dengan tema "Memilih Sesuatu yang Menarik" untuk dibagikan kepada siswa.

5) Guru membentuk kelompok siswa untuk memerankan skenario role play.

6) Guru mempersiapkan rekaman percakapan diskusi yang akan diperdengarkan kepada siswa sebagai contoh.

7) Guru mempersiapkan transkrip rekaman diskusi untuk dibagikan kepada siswa.

8) Guru menyusun instrumen penelitian yang berupa penilaian tes dan nontes. Instrumen tes dinilai dari hasil praktik berbicara siswa dalam bentuk diskusi (sesuai kompetensi dasar yang ingin dicapai). Untuk instrumen nontes dinilai berdasarkan hasil observasi yang dilakukan oleh peneliti dan berdasarkan rubrik penilaian proses pembelajaran berbicara yang meliputi: (a) kedisiplinan, (b) minat, (c) keaktifan, (d) kerja sama, dan (e) kesungguhan siswa selama pembelajaran berlangsung.

\section{b. Pelaksanaan Tindakan}

Dalam pelaksanaan tindakan I ini, peneliti bertindak sebagai guru dalam kegiatan pembelajaran berbicara, sedangkan rekan sejawat gurubertindak sebagai observer melakukan observasi atau pengamatan terhadap proses pembelajaran. Peneliti bertindak sebagai partisipan pasif yang berada di belakang ruang kelas untuk mengamati jalannya pembelajaran. Pelaksanaan tindakan siklus I pertemuan pertama dilaksanakanselama dua jam pelajaran.

Adapun urutan pelaksanaan tindakan I pertemuan pertama ini meliputi langkah-langkah sebagai berikut:

a. Guru membuka pelajaran dan memberikan apersepsi dengan menggalipengalaman siswa dalam kehidupan sehari-hari yang berkaitan dengan materi berbicara.

b. Guru dan siswa melakukan tanya jawab tetang jenis kegiatan berbicara.

c. Guru memberikan penjelasan tentang materi diskusi.

d. Guru memperdengarkan rekaman percakapan diskusi sambil Membagikan transkrip hasil rekaman tersebut sebagai contoh.

e. Guru membagi siswa menjadi 5 kelompok (masing-masing beranggotakan 4 orang).

f. Guru menugasi masing-masing kelompok untuk melakukan diskusi dengan metode bermain peran. Tema diskusi adalah "Memilih Sesuatu yang Menarik".

g. Guru dan siswa melakukan tahap persiapan, yaitu: membagikan Skenario role play, menentukan peran yang akan dimainkan setiap peserta, menjelaskan skenario, menentukan aturan permainan, dan menjelaskan tujuan pembelajaran.

h. Siswa melakukan role play secara berkelompok. Setiap kelompok diberi waktu 8 menit, dengan rincian 5 menit untuk pemeranan dan 3 menit untuk refleksi dan evaluasi 
i. Guru bersama siswa lain mengamati penampilan kelompok pemain.

j. Di setiap akhir penampilan, guru melakukan refleksi dan evaluasi tahap I(yaitu guru bersama siswa pengamat memberikan kritik, masukan, dan komentar).

k. Guru meminta siswa mempersiapkan diri untuk melakukan penampilan ulang pada pertemuan berikutnya

1. Guru menutup pelajaran.

Pembelajaran berbicara dilanjutkan pada pertemuan kedua. Pelaksanaan tindakan I pertemuan kedua tersebut dilaksanakan pada hari Selasa 8 Septenber 2009. selama satu jam pelajaran, yaitu pukul 08.40- 09.15 WIB(jam pelajaran ke-2). Adapun urutan pelaksanaan tindakan I pertemuan kedua ini meliputi langkah-langkah sebagai berikut:

1) Guru membuka pelajaran dan mengulang sekilas materi pelajaran yang telah disampaikan pada pertemuan sebelumnya dengan melakukan tanya jawab dengan siswa

2) Guru meminta siswa menampilkan ulang kegiatan diskusi mereka dengan metode bermain peran

3) Di akhir penampilan semua kelompok, guru melakukan refleksi dan evaluasi tahap II (yaitu bersama siswa pengamat memberikan kritik,masukan, dan komentar kepada siswa pemain).

4) Guru menutup pelajaran.

c. Observasi dan interpretasi

Observasi/pengamatan yang dilakukan oleh teman sejawat guru sebagai observermenyampaikan. Pada hari itu guru mengajarkan materi diskusi dengan tema "Memilih Sesuatu yang Menarik". Pengamatan difokuskan pada berlangsungnya proses pelaksanaan pembelajaran, serta aktivitas siswa dan guru selama pembelajaran berlangsung. Berdasarkan pengamatan, secara garis besar diperoleh gambaran tentang jalannya kegiatan belajar mengajar (KBM) sebagai berikut:

a. Sebelum mengajar, guru telah mempersiapkan rencana pembelajaran yang akan dijadikan sebagai pedoman dalam mengajar. Rencana pembelajaran tersebut sesuai dengan silabus mata pelajaran Bahasa Indonesia yang terdapat di dalam kurikulum yang berlaku, yakni kurikulum tingkat satuan pendidikan (KTSP).

b. Pelaksanaan tindakan siklus I yang berlangsung dalam dua kali pertemuan, dihadiri dan diikuti oleh semua siswa kelas IV yang berjumlah 20 orang.

c. Guru melaksanakan kegiatan pembelajaran berbicara dengan cukup baik, yaitu guru mengajar dengan arah dan tujuan yang jelas dan terencana Pada awal pembelajaran, guru dengan jelas mengemukakan apa yang akan diajarkan hari itu kepada siswa, yaitu tentang diskusi. Selanjutnya memberikan apersepsi guna menggali pengalaman siswa mengenai materi tersebut dan memberi penjelasan terlebih dahulu mengenai aturan-aturan metode bermain peran yang akan digunakan dalam pelajaran diskusi.

d. Saat guru menyampaikan materi, sebagian besar siswa tampak antusias dan beberapa siswa lainnya tampak kurang berminat, tampak malas, melamun, mengganggu teman, dan beraktivitas sendiri.

e. Setelah guru memberikan cukup penjelasan, selanjutnya siswa diberi tugas berbicara, yaitu diskusi. Berbeda dengan biasanya, kali ini tugas diskusi siswa dilakukan dengan menggunakan metode bermain peran, di mana siswa dibagi dalam lima kelompok untuk memerankan tokoh-tokoh yang sedang terlibat dalam situasi diskusi. Adapun skenario untuk kelima kelompok adalah sama, yaitu memerankan skenario mengenai tugas ketua kelas yang sedang melakukan diskusi bersama dengan beberapa siswa lain mengenai rencana kegiatan liburan sekolah minggu depan. Di setiap 
kelompok, masing-masing anak berperan sebagai ketua kelas, wakil ketua kelas, dan sisanya sebagai siswa biasa.

f. Kelima kelompok tampil secara berurutan, dan di saat satu kelompok tampil, tugas siswa lain dan guru adalah menjadi pengamat yang akan memberikan komentar di akhir penampilan tersebut. Walaupun guru memberikan skenario yang sama, tetapi tidak semua kelompok dapat mengembangkan skenario tersebut dengan baik. Dari kelima penampilan kelompok, hanya kelompok satu dan lima saja yang terlihat maksimal dan mampu mengembangkan skenario sehingga menghasilkan percakapan diskusi yang panjang dan asyik.

g. Saat tahap evaluasi dan refleksi, jumlah siswa yang mau memberikankomentar hanya beberapa saja ( 5 orang), itu pun hanya siswa yang berperan sebagai ketua kelas di masing-masing kelompoknya. Sementara itu siswa yang lain hanya diam mendengarkan, mereka masih tampak sungkan dan takut untuk menyampaikan pendapatnya.

h. Ketuntasan hasil belajar mencapai sekitar $10 \%$. Hal ini terlihat dari hasil praktik berbicara (bentuk diskusi) dan dihitung dari jumlah siswa yang memperoleh nilai 60 (batas ketuntasan) ke atas, yaitu sebanyak 2 siswa.

\section{d. Analisis dan refleksi}

Keberhasilan proses pembelajaran berbicara siklus I dapat dilihat dari beberapa indikator berikutini:

a) Kedisiplinan

Siswa yang menunjukkan kedisiplinan dalam mengikuti pembelajaran berbicara sebanyak 2 orang atau sekitar $10 \%$, sedangkan 18 orang atau sekitar 90\% lainnya menunjukkan sikap kurang disiplin atau kurang tertib mengikuti setiap kegiatan pembelajaran di kelas.

b) Minat

Minat siswa terhadap pembelajaran berbicara dengan penerapan metode bermain peran di siklus I, telah menunjukkan peningkatan dari kondisi awal sebesar 5\% menjadi sebesar $10 \%$. Siswa tampak tertarik dan lebih antusias mengikuti pembelajaran dengan metode bermain peran, sehingga perhatian siswa pun lebih terfokus pada pelajaran. Adapun indikator pengukuran minat siswa dapat dilihat dari hasil pengamatan peneliti dan diukur dari jumlah siswa yang menampakkan ketertarikan dan kesungguhannya dalam pembelajaran.

c) Keaktifan

Keaktifan siswa dalam pembelajaran meningkat. Siswa terlihat lebih aktif untuk merespons stimulus dari guru, aktif mengungkapkan gagasan dan perasaannya secara lisan, aktif melakukan kegiatan tanya jawab, dan aktif mengerjakan tugas-tugas yang diberikan oleh guru. Keaktifan siswa dapat diamati selama proses pembelajaran berlangsung.

d) Kerja sama

Siswa yang menunjukkan sikap kerja sama yang baik selama mengikuti pembelajaran berbicara sebesar $10 \%$ atau sebanyak 2orang, sedangkan $90 \%$ atau 18 orang sisanya tampak belum mampu melakukan kerja sama yang baik dengan anggota kelompoknya.

e) Kesungguhan

Siswa yang menunjukkan kesungguhan dalam mengikuti pembelajaran berbicara sebanyak 2 orang atau sebesar 10\%, sedangkan 18 orang lainnya atau sekitar 90\% menunjukkan sikap kurang serius selama mengikuti pelajaran. Terlebih pada saat melakukan praktik berbicara di depan kelas, mereka terlihat kurang bersungguh-sungguh dan sering bercanda dengan sesama teman kelompoknya. Selain meningkatkan kualitas proses pembelajaran, penerapan metode bermain peran ini juga ikut meningkatkan hasil pembelajaran berbicara. Hal ini terbukti dari 20 siswa 
yang melakukan tes berbicara, 2 siswa atau sekitar $10 \%$ telah mencapai ketuntasan belajar dengan mendapat nilai 60 ke atas. Ketuntasan belajar ini mengalami peningkatan dari kondisi awal sekitar 5\% atau sebanyak 2 siswa saja yang memenuhi standar ketuntasan.

Selanjutnya berdasarkan hasil pertemuan dan diskusi dengan beberapa siswa mengenai kekurangan pelaksanaan pembelajaran siklus I, peneliti merumuskan perencanaan pembelajaran yang baru sebagai bahan perbaikan, yaitu:

a) Mengganti prosedur/langkah-langkah kegiatan pembelajaran yang pada awalnya hanya berupa kegiatan ceramah dan tanya jawab, di siklus II ditambahi dengan kegiatan penugasan. Meskipun metode pembelajaran tetap menggunakan bermain peran, tetapi tema diskusi diganti. Pada siklus I mengangkat tema "Memilih Sesuatu yang Menarik", maka di siklus II ini mengambil tema lain, yaitu "Peristiwa".

b) Sebaiknya posisi guru saat pembelajaran tidak hanya berada di depan kelas. Guru juga harus berkeliling untuk memonitor siswa yang berada di tempat duduk deretan belakang, pojok, dan samping agar mereka dapat ikut berpartisispasi aktif dalam kegiatan pembelajaran. Selain itu guru harus lebih tegas menegur siswa yang tidak fokus saat mengikuti pembelajaran.

c) Guru menjadikan situasi belajar lebih aktif dan tidak cenderung monoton (membosankan) dengan memberikan selingan humor dan lebih mengakrabkan diri dengan siswa.

d) Untuk meningkatkan minat siswa, guru bisa melakukannya dengan sekedar memberikan tepuk tangan, reward berupa pujian seperti: bagus sekali, baik sekali, tepat sekali, atau bisa juga memberi nilai plus/tambahan kepada siswa, atau pun memberi hadiah bagi siswa yang telah mencapai nilai 60 ke atas.

e) Siswa yang merasa kurang jelas diberikan bimbingan/arahan secara khusus dalam melakukan pembelajaran berbicara dengan metode bermain peran, seperti memberi tambahan penjelasan mengenai peraturan bermain peran dan skenarionya.

f) Diakhir pembelajaran hendaknya guru tidak lupa memberikan refleksi, umpan balik atau penguatan atas materi yang telah disampaikan.

Perencanaan pembelajaran baru ini diharapkan mampu mengatasi kekurangan yang ada di siklus I.

e. Siklus Kedua (II)

a. Perencanaan Tindakan

Pelaksanaan tindakan siklus II akan dilaksanakan dalam dua kali pertemuanTahap perencanaan tindakan ini meliputi kegiatan sebagai berikut:

1) Guru merancang skenario pembelajaran berbicara dengan penerapan metode bermain peran, dengan langkah-langkah sebagai berikut: (a) Guru membuka pelajaran dan memberikan apersepsi dengan menggali pengalaman siswa yang berkaitan dengan materi pelajaran berbicara pada saat itu. (b) Guru melakukan tanya jawab dengan siswa seputar pengetahuannya tentang berbagai macam peristiwa faktual yang sedang terjadi di lingkungan sekitar. (c) Guru mengawali kegiatan inti dengan mengatur tempat duduk siswa sesuai kelompok yang telah dibentuk pada pertemuan sebelumnya. (d) Guru membagikan surat kabar kepada masingmasing kelompok, kemudian memintanya untuk mendata berbagai peristiwa faktual yang sedang terjadi didalamnya. (e) Guru bersama siswa mengidentifikasi sebuah peristiwa faktual yang sedang terjadi di berbagai daerah, yaitu banjir. (f) Guru menugasi setiap kelompok untuk melakukan diskusi tentang peristiwa "Banjir" dengan metode bermain peran. (g) Guru 
dan siswa melakukan tahap persiapan, yaitu: membagikan skenario role play, menentukan peran yang akan dimainkan setiap peserta, menjelaskan skenario, menentukan aturan permainan, dan menjelaskan tujuan pembelajaran. (h) Siswa melakukan role play secara berkelompok. Setiap kelompok diberi waktu 8 menit, dengan rincian 5 menit untuk pemeranan dan 3 menit untuk refleksi dan evaluasi. (i) Guru bersama siswa lain mengamati penampilan kelompok pemain. (j) Di setiap akhir penampilan, guru melakukan refleksi dan evaluasi tahap I (yaitu guru bersama siswa pengamat memberikan kritik, masukan, dan komentar). (k) Berdasarkan hasil refleksi dan evaluasi tahap I, guru meminta siswa untuk menampilkan ulang perannya. (l) Guru melakukan refleksi dan evaluasi tahap II diakhir penampilan siswa dan memberikan kesempatan kepada mereka untuk menanyakan hal-hal yang belum dipahami. (m) Guru menutup pelajaran.

2) Guru (Peneliti) menyusun Rencana Pelaksanaan Pembelajaran (RPP).

3) Guru (Peneliti) mempersiapkan materi dan membuat skenariorole play siklus II dengan tema "Peristiwa" untuk dibagikan kepada siswa.

4) Guru mempersiapkan surat kabar.

5) Guru (Peneliti) menyusun instrumen penelitian yang berupa penilaian tes dan nontes. Instrumen tes dinilai dari hasil praktik berbicara siswa dalam bentuk diskusi (sesuai kompetensi dasar yang ingin dicapai). Untuk instrumen nontes dinilai berdasarkan hasil observasi yang dilakukan oleh peneliti dan berdasarkan rubrik penilaian proses pembelajaran berbicara yang meliputi: (a) kedisiplinan, (b) minat, (c) keaktifan, (d) kerja sama, dan (e) kesungguhan siswa selama pembelajaran berlangsung.

\section{f. Pelaksanaan Tindakan}

Adapun urutan pelaksanaantindakan II pertemuan pertama ini meliputi langkah-langkah sebagai berikut:

1) Guru membuka pelajaran dan memberikan apersepsi dengan menggali pengalaman siswa yang berkaitan dengan materi pelajaran berbicara pada saat itu.

2) Guru melakukan tanya jawab dengan siswa seputar pengetahuannya tetang berbagai macam peristiwa faktual yang sedang terjadi di lingkungan sekitar.

3) Guru mengawali kegiatan inti dengan mengatur tempat duduk siswa sesuai kelompok yang telah dibentuk pada pertemuan sebelumnya.

4) Guru membagikan surat kabar kepada masing-masing kelompok, kemudian memintanya untuk mendata berbagai peristiwa faktual yang sedang terjadi didalamnya.

5) Guru bersama siswa mengidentifikasi sebuah peristiwa faktual yang sedang terjadi di berbagai daerah, yaitu banjir.

6) Guru menugasi setiap kelompok untuk melakukan diskusi tentang peristiwa "Banjir" dengan metode bermain peran.

7) Guru dan siswa melakukan tahap persiapan, yaitu: membagikan skenario role play, menentukan peran yang akan dimainkan setiap peserta, menjelaskan skenario, menentukan aturan permainan, dan menjelaskan tujuan pembelajaran.

8) Siswa melakukan role play secara berkelompok. Setiap kelompok diberi waktu 8 menit, dengan rincian 5 menit untuk pemeranan dan 3 menit untuk refleksi dan evaluasi.

9) Guru bersama siswa lain mengamati penampilan kelompok pemain.

10) Di setiap akhir penampilan, guru melakukan refleksi dan evaluasi tahap I (yaitu guru bersama siswa pengamat memberikan kritik, masukan, dan komentar). 
11) Guru meminta siswa mempersiapkan diri untuk melakukan penampilan ulang pada pertemuan berikutnya.

12) Guru melakukan refleksi (memberikan kesempatan kepada siswa untuk menanyakan hal-hal yang belum mereka pahami), kemudian menutup pelajaran.

Pembelajaran berbicara dilanjutkan pada pertemuan kedua.Adapun urutan pelaksanaan tindakan II pertemuan kedua ini meliputi langkah-langkah sebagai berikut:

1) Guru membuka pelajaran dan mengulang sekilas materi pelajaran yang telah disampaikan pada pertemuan sebelumnya dengan melakukan tanya jawab dengan siswa.

2) Guru meminta siswa menampilkan ulang diskusi kedua mereka tentang banjir dengan metode bermain peran.

3) Di akhir penampilan ulang semua kelompok, guru melakukan refleksi dan evaluasi tahap II (yaitu bersama siswa pengamat memberikan kritik, masukan dan komentar kepada siswa pemain).

4) Guru memberi kesempatan kepada siswa untuk menanyakan hal-hal yangbelum jelas, selanjutnya guru menutup pelajaran.

g. Observasi dan interpretasi

Kegiatan peneliti selama kegiatan diamati oleh rekan sejawat guru sebagai observer menyampaikan. Pada hari itu guru mengajarkan materi diskusi dengan tema "Peristiwa". Pengamatan difokuskan pada berlangsungnya proses pelaksanaan pembelajaran, serta aktivitas siswa dan guru selama pembelajaran berlangsung. Selain itu, kegiatan observasi siklus II ini dimaksudkan untuk mengetahui apakah kelemahan di dalam proses pembelajaran pada siklus I sudah bisa teratasi atau belum. Dalam pengamatan ini, peneliti bertindak sebagai partisipan pasif yang berada di belakang ruang kelas agar bisa mengamati proses pembelajaran yang dipimpin oleh guru.

Berdasarkan pengamatan peneliti, secara garis besar diperoleh gambaran tentang jalannya kegiatan belajar mengajar sebagai berikut:

1) Sebelum mengajar, guru telah mempersiapkan rencana pembelajaran yang akan dijadikan sebagai pedoman dalam mengajar. Rencana pembelajaran Tersebut sesuai dengan silabus mata pelajaran Bahasa Indonesia yang terdapat di dalam kurikulum yang berlaku, yakni urikulum tingkat satuan pendidikan (KTSP).

2) Pelaksanaan tindakan siklus II berlangsung selama dua kali pertemuan. Pada pertemuan pertama, jumlah siswa hadir .20 orang dan pada pertemuan kedua semua siswa kelas IV yang berjumlah 20 orang hadir.

3) Guru melaksanakan kegiatan pembelajaran berbicara dengan baik dan runtut, sesuai dengan rancangan pembelajaran yang dibuat.

4) Saat guru menyampaikan materi, sebagian besar siswa mengikuti dengan baik. Namun, masih ada juga beberapa siswa yang tampak kurang serius memperhatikan. Berdasarkan observasi pada siklus I, siswa yang kurang serius mengikuti pelajaran disebabkan karena munculnya kebosanan pada diri mereka, sehingga di siklus II ini untuk menyampaikan materi guru tidak hanya terpaku pada buku melainkan membawa sumber rujukan lain, yaitu surat kabar. Surat kabar tersebut dibagikan kepada setiap kelompok, selanjutnya guru meminta mereka untuk mencari dan mengidentifikasi peristiwa faktual yang ada didalamnya. Kegiatan mencari data dari surat kabar ini terbukti mampu membuat siswa semakin tertarik mengikuti pelajaran.

5) Setelah penyampaian materi selesai, selanjutnya siswa diberi tugas berbicara/diskusi dengan menggunakan metode yang sama juga, yaitu bermain peran. Tema pelajaran di siklus II adalah "Peristiwa". Adapun skenario untuk kelima kelompok adalah sama, yaitu siswa disuruh untuk 
memerankan skenario yang berisi tentang pembicaraan kepala desa bersama dengan beberapa warganya mengenai musibah banjir yang sedang melanda daerahnya. Di setiap kelompok, masing-masing anak berperan sebagai kepala desa, ketua RT, dokter, dan sisanya warga desa/korban banjir.

6) Kelima kelompok tampil secara berurutan, dan di saat satu kelompok tampil, tugas siswa lain dan guru adalah menjadi pengamat yang akan memberikan komentar di akhir penampilan tersebut. Penampilan kelima kelompok semakin menunjukkan perkembangan, hampir semua siswa telah mampu mengembangkan idenya.

7) Saat tahap evaluasi dan refleksi, jumlah siswa yang mau memberikan komentar semakin bertambah. Hal ini dikarenakan guru telah menjalankan saran dari analisis tindakan di siklus I, yaitu dengan memberikan reward, baik berwujud nilai tambahan maupun pujian bagi siswa yang dapat mengemukakan pendapatnya dengan tepat. Usaha pemberian reward ini ternyata terbukti mampu membangkitkan minat siswa untuk mengungkapkan komentar mereka, serta merespons pertanyaan dari guru secara sukarela.

8) Ketuntasan hasil belajar yang berupa kemampuan siswa dalam mengungkapan pendapat, ide, gagasan, dan perasaannya dalam kegiatan diskusi mencapai sekitar 85\% . Hal ini terlihat dari hasil praktik berbicara (bentuk diskusi) dan dihitung dari jumlah siswa yang memperoleh nilai 60 (batas ketuntasan) ke atas, yaitu sebanyak 17 siswa.

h. Siklus Ketiga (III)

a. Perencanaan Tindakan

Pelaksanaan tindakan siklus III akan dilaksanakan dalam dua kali pertemuan. Tahap perencanaan tindakan ini meliputi kegiatan sebagai berikut:

1) Peneliti merancang skenario pembelajaran berbicara dengan penerapan metode bermain peran.

2) Peneliti menyusun Rencana Pelaksanaan Pembelajaran (RPP).

3) Peneliti mempersiapkan materi dan membuat skenario role play siklus III dengan tema "Kesehatan" untuk dibagikan kepada siswa.

4) Peneliti dan guru menyusun instrumen penelitian yang berupa penilaian tes dan nontes. Instrumen tes dinilai dari hasil praktik berbicara siswa dalam bentuk diskusi (sesuai kompetensi dasar yang ingin dicapai). Untuk instrumen nontes dinilai berdasarkan hasil observasi yang dilakukan oleh peneliti dan berdasarkan rubrik penilaian proses pembelajaran berbicara yang meliputi: (a) kedisiplinan, (b) minat, (c) keaktifan, (d) kerja sama, dan (e) kesungguhan siswa selama pembelajaran berlangsung.

i. Pelaksanaan Tindakan

Dalam pelaksanaan tindakan III ini, peneliti bertindak sebagai guru pemimpin jalannya kegiatan pembelajaran berbicara, sedangkan rekan sejawat guru sebagai observer melakukan observasi atau pengamatan terhadap proses pembelajaran.

Adapun urutan pelaksanaan tindakan III pertemuan pertama ini meliputi langkah-langkah sebagai berikut:

a. Guru melakukan tanya jawab dengan siswa seputar pengetahuannya tetang materi drama.

b. Guru memberi penjelasan tentang materi drama dan menunjukkan contoh dialog drama dari buku pelajaran.

c. Guru meminta siswa membaca dialog drama tersebut.

d. Guru menugasi siswa untuk bermain drama dengan tema kesehatan, secara berkelompok. 
e. Guru dan siswa melakukan tahap persiapan, yaitu: membagikan skenario role play yang akan dikembangkan menjadi kerangka naskah drama pendek oleh masing-masing kelompok, menentukan peran yang akan dimainkan setiap peserta, menentukan aturan permainan, dan menjelaskan tujuan pembelajaran.

f. Setelah tahap persiapan selesai, guru meminta siswa untuk memulai kegiatan bermain drama berdasarkan skenario yang telah ditentukan dengan metode bermain peran secara berkelompok. Setiap kelompok mendapatkan waktu 8 menit dengan rincian 5 menit untuk pemeranan dan 3 menit untuk refleksi dan evaluasi.

g. Guru bersama siswa lain mengamati penampilan kelompok pemain.

h. Di setiap akhir penampilan, guru melakukan refleksi dan evaluasi tahap I (yaitu guru bersama siswa pengamat memberikan kritik, masukan, dan komentar).

i. Guru meminta siswa mempersiapkan diri untuk melakukan penampilan ulang pada pertemuan berikutnya.

j. Guru melakukan refleksi (memberikan kesempatan kepada siswa untuk menanyakan hal-hal yang belum mereka pahami), kemudian menutup pelajaran.

Pembelajaran berbicara dilanjutkan pada pertemuan kedua. Adapun urutan pelaksanaan tindakan III pertemuan kedua ini meliputi langkah-langkah sebagai berikut:

1) Guru membuka pelajaran dan mengulang sekilas materi pelajaran yang telah disampaikan pada pertemuan sebelumnya dengan melakukan tanya jawab dengan siswa.

2) Guru meminta siswa menampilkan ulang drama pendek mereka setelah mendapat evaluasi dari guru dan teman kelompok yang lain pada pertemuan sebelumnya (secara bergantian).

3) Di akhir penampilan ulang semua kelompok, guru melakukan refleksi dan evaluasi tahap II (yaitu bersama siswa pengamat memberikan kritik,masukan, dan komentar kepada siswa pemain).

4) Guru memberi kesempatan kepada siswa untuk menanyakan hal-hal yang belum jelas, selanjutnya guru menutup pelajaran.

\section{j. $\quad$ Observasi dan interpretasi}

Pada siklus III ini guru juga menerapkan bermain peran sebagai metode pembelajaran berbicara, namun kompetensi dasar yang dijadikan pedoman berbeda dengan kompetensi dasar pembelajaran berbicara di kedua siklus sebelumnya, yaitu" Memerankan Tokoh Drama dengan Lafal, Intonasi, dan Ekspresi yang Tepat". Alasan guru mengganti kompetensi dasar tersebut adalah gar siswa tidak merasa bosan melakukan praktik berbicara dalam bentuk diskusi yang telah dilakukan dalam siklus I dan II. Meskipun ada perubahan kompetensi dasar yang digunakan, namun dasar pembelajaran tetap bertumpu pada standar kompetensi yang sama, yaitu "Mengungkapkan Pikiran dan Perasaan Secara Lisan dalam Diskusi dan Bermain Drama". Pengamatan difokuskan pada berlangsungnya proses pelaksanaan pembelajaran, serta aktivitas siswa dan guru selama pembelajaran berlangsung. Selain itu, kegiatan observasi siklus III ini dimaksudkan untuk mengetahui apakah kelemahan di dalam proses pembelajaran pada siklus II sudah bisa teratasi atau belum.

Setelah penyampaian materi selesai dan siswa merasa paham, selanjutnya siswa diberi tugas berbicara. Berbeda dengan pelaksanaan kedua siklus sebelumnya, dalam siklus III ini tugas yang harus dikerjakan siswa, yaitu melakukan kegiatan bermain drama (sesuai dengan kompetensi dasar) yang juga dipraktikkan dengan menggunakan metode bermain peran. Tema 
pelajaran di siklus III yaitu "Kesehatan". Adapun skenario yang akan diperankan oleh kelima kelompok adalah sama, yaitu memerankan suatu kejadian tentang akibat yang diterima seorang anak karena suka jajan sembarangan.

Kelima kelompok tampil secara berurutan, dan di saat satu kelompok tampil, tugas siswa lain dan guru adalah menjadi pengamat yang akan memberikan komentar di akhir penampilan tersebut. Penampilan kelima kelompok semakin menunjukkan peningkatan. Semua siswa sudah mampu berbicara dengan lancar, terampil mengungkapkan pikiran dan perasaannya dengan bahasa yang baik, dan mampu mengmbangkan skenario yang diberikan menjadi sebuah cerita yang berbeda-beda antarkelompok.

Saat tahap evaluasi dan refleksi, hampir semua siswa telah memberikan komentar dan komentar tersebut semakin beragam. Siswa terlihat semakin berani dan terampil menggunakan bahasa lisan. Hal ini dikarenakan guru selalu berusaha memberikan motivasi demi meningkatkan minat dankeaktifan siswa.Selama proses pembelajaran berlangsung, hampir semua siswa mengikutinya dengan baik, tertib dan penuh kesungguhan.

Kelemahan atau kekurangan selama pelaksanaan tindakan siklus III hampir tidak terlihat lagi. Dengan kata lain, guru telah mampu mengatasi segala kelemahan yang terjadi pada kedua siklus sebelumnya dengan baik. Siswa telah menunjukkan perbaikan sikap dalam mengikuti pembelajaran, hanya ada sedikit saja kelemahan yang masih terlihat di dalam pelaksanaan tindakan siklus III ini yang ditemukan dari metode bermain peran, yaitu lebih mengarah pada sifat dan karakteristik bermain peran itu sendiri. Di mana pada dasarnya bermain peran berwujud sebuah permainan, peraturannya pun bersifat fleksibel (mudah diubah dan disesuaikan dengan keadaan), sehingga pelaksanaannya cenderung didasarkan pada sifat bermain/permainan. Hal seperti inilah yang membuat beberapa siswa kurang serius, karena dia merasa sedang berada dalam situasi bermain bukan belajar.

Ketuntasan hasil belajar yang berupa kemampuan siswa dalam mengungkapan pendapat, ide, gagasan, dan perasaannya dalam kegiatan bermain drama mencapai $100 \%$. Hal ini terlihat dari hasil praktik berbicara dan dihitung dari jumlah siswa yang memperoleh nilai 60 (batas ketuntasan) ke atas, yaitu sebanyak 20 siswa.

k. Analisis dan refleksi

Keberhasilan proses pembelajaran berbicara siklus III dapat dilihat dari beberapa indikator berikut ini:

a. Kedisiplinan

Siswa yang menunjukkan kedisiplinan dalam mengikuti pembelajaran berbicara di siklus III ini, jumlahnya tidak berubah dari siklus II, yaitu sebanyak 17 orang atau sekitar $85 \%$.

b. Minat

Minat siswa terhadap pembelajaran berbicara dengan penerapan metode bermain peran di siklus III telah menunjukkan adanya peningkatan dari siklus II sebesar $85 \%$ menjadi sebesar 100 \%. Penerapan metode bermain peran ini berhasil membuat siswa lebih berminat dan termotivasi mengikuti pembelajaran keterampilan berbicara. Minat dan motivasi ini sangat menentukan keberhasilan belajar siswa, sehingga siswa merasa lebih tertarik dan tertantang untuk semakin mengasah kemampuannya dalam kegiatan berbicara. Selain itu siswa juga terlihat lebih rileks di dalam mengikuti proses pembelajaran, hal ini disebabkan karena situasi 
pembelajaran yang tercipta melalui penerapan metode bermain peran hampir sama dengan situasi bermain. Jadi siswa merasa lebih nyaman dan mudah dalam menginterpretasikan tugas berbicara mereka.

c. Keaktifan

Keaktifan siswa dalam pembelajaran berbicara siklus III telah mengalami peningkatan dari siklus II sebesar $55.67 \%$ menjadi sebesar $77.79 \%$. Berdasarkan pengamatan selama proses pembelajaran berlangsung, terbukti siswa terlihat lebih aktif untuk merespons stimulus dari guru, aktif mengungkapkan gagasan dan perasaannya secara lisan, aktif melakukan kegiatan tanya jawab, dan aktif mengerjakan tugas-tugas yang diberikan oleh guru.

d. Kerja Sama

Kerja sama siswa di siklus III ini mengalami penurunan dari siklus II, yaitu dari $85 \%$ menjadi $10 \%$. Berdasarkan observasi, penurunan kerja sama siswa tersebut terindikasi dari sikap masing-masing siswa yang lebih menonjolkan kemampuan pribadinya, walaupun tugas berbicara di siklus III ini adalah bermain drama tetapi mereka seakan-akan ingin menunjukkan diri sebagai yang terbaik. Hal seperti itulah yang membuat penampilan setiap kelompok terlihat tidak kompak lagi seperti pada tugas diskusi sebelumnya.

e. Kesungguhan

Siswa yang menunjukkan kesungguhan dalam mengikuti pembelajaran berbicara di siklus III ini juga mengalami penurunan dari siklus sebelumnya, yaitu dari $85 \%$ menjadi $10 \%$. Berdasarkan pengamatan dari guru, penurunan kesungguhan belajar siswa ini tampak dari tingkah laku sebagian besar siswa yang menunjukkan sikap kurang serius selama mengikuti pelajaran. Terlebih pada saat melakukan tugas berbicara di depan kelas (bermain drama), mereka terlihat kurang bersungguh-sungguh dan sering bercanda dengan sesama teman kelompoknya. Penerapan metode bermain peran ini selain meningkatkan kualitas proses pembelajaran, juga ikut meningkatkan hasil pembelajaran berbicara siswa. Berdasarkan hasil evaluasi di akhir tindakan siklus III, diketahui bahwa kemampuan berbicara siswa mengalami peningkatan dari siklus II sebesar $85 \%$ menjadi $100 \%$. Hal ini terbukti dari 20 siswa yang melakukan praktik berbicara, semuanya telah mencapai ketuntasan belajar dengan mendapat nilai 60 ke atas.Dengan adanya refleksi dan perbaikan langkah-langkah pembelajaran di setiap akhir kedua siklus sebelumnya, maka kelemahan atau kekurangan dari pelaksanaan tindakan siklus III ini hampir tidak terlihat lagi. Guru sudah mampu menciptakan situasi belajar yang mendukung siswa untuk lebih aktif. Meskipun pada siklus III terjadi penurunan persentase kerja sama dan kesungguhan siswa, namun hal tersebut tidak menjadi masalah yang berarti karena sejak awal proses pembelajaran yang diamati hanya terfokus pada minat dan keaktifan siswa saja dan dapat dikatakan secara keseluruhan proses dan hasil pembelajaran mengalami peningkatan yang sangat memuaskan.

\section{Pembahasan}

Metode bermain peran menurut Iswandi (2012: 5) merupakan salah satu metode yang dapat menyajikan bahan pelajaran dengan cara memainkan peran dan mendramatisasikan suatu situasi sosial yang mengandung suatu masalah dengan harapan agar peserta didik da[at memecahkan masalah yang dihadapi dalam hubungan sosial. Menurut Miftahul Huda (2014: 208), metode bermain peran adalah suatu bentuk aktivitas dimana pembelajaran membayangkan dirinya seolah-olah berada di luar kelas dan memainkan peran orang lain. Dari pendapat di atas, dapat 
disimpulkan bahwa metode bermain peran merupakan suatu bentuj pembelajaran dengan menampilkan peran - peran orang lain yang diperagakan siswa dengan harapan dapat mencari solusi dari masalah yang dihadapai, sehingga siswa dapat mengembangkan daya imajinasi serta kreativitasnya masing - masing. Sedangkan menurut Hamdani (2011: 87), metode bermain peran (role playing) adalah cara penguasaan bahan - bahan pelajaran melalui pengembangan imajinasi dan penghayatan siswa.

Metode bermain peran bertujuan menggambarkan suatu peristiwa masa lampau atau dapat pula cerita dimulai dengan berbagai kemungkinan yang terjadi baik sekarang maupun masa yang akan datang, kemudian ditunjuk beberapa orang siswa untuk melakukan peran sesuai dengan tujuan cerita. Bermain peran hampir sama dengan percakapan, hanya saja dalam percakapan seseorang memerankan diri sendiri, sedangkan dalam bermain peran, seseorang memerankan orang lain (Solchan, 2009: 11.39).

Menurut Oemar Hamalik (2009: 199), ada 4 (empat) tujuan metode bermain peran, yaitu:

1. Belajar dengan berbuat, para siswa melakukan peran tertentu sesuai dengan kenyataan yang sesungguhnya, dengan tujuan untuk mengembangkan keterampilan - keterampilan interaktif dan kreatif.

2. Belajar melalui peniruan, para siswa pengamat drama menyamakan diri dengan pelaku dan tingkah laku mereka.

3. Belajar melalui para pengamat mengometari/menanggapi perilaku para pemain yang telah ditampilkan, yang bertujuan untuk mengembangkan prosedur prosedur kognitif dan prinsip - prinsip yang mendasari perilaku keterampilan yang telah didramatisasikan.

4. Belajar melalui pengkajian, penilaian dan pengulangan siswa daoat memperbaiki keterampilan - keterampilan mereka dalam penampilan berikutnya.

Kelebihan dan kekurangan dalam metode bermain peran menurut Miftahul Huda (2014: 210), yaitu:

$>$ Kelebihan:

a) Memberikan kesan yang kuat dan tahan lama dalam ingatan siswa.

b) Bisa menjadi pengalaman belajar yang menyenangkan yang sulit untuk dilupakan. Membuat suasana kelas menjadi antusias.

c) Membangkitkan gairah dan semangat optimisme dalam diri siswa serta menumbuhkan rasa kebersamaan.

d) Memungkinkan siswa untuk terjun langsung memerankan sesuati yang akan dibahas.

$>$ Kekurangan:

a) Banyak waktu yang diperlukan.

b) Kesulitan menugaskan peran tertentu kepada siswa jika tidak dilatih dengan baik.

c) Membutuhkan persiapan yang benar - benar matang yang akan menghabiskan waktu dan tenaga.

Menurut Sumiati (2009:100), ada beberapa karakteristik metode bermain peran, yaitu:

e) Jika siswa baru pertama kali melakukan permainan bermain peran, berilah penjelasan singkat tentang bermain peran.

f) Guru menyampaikan cerita, kemudian mengatur adegan - adegan permainan.

g) Guru meminta sejumlah siswa (sesuai kebutuhan) untuk memainkan peran secara singkat, kepada yang tidak bermain diminta untuk memperhatikan baikbaik. 
h) Memberi petunjuk sekedarnya tentang darimana permainan dimulai.

i) Pada saat situasi permainan memuncak, guru menghentikan permainan.

j) Diskusi tentang berbagai hal berkaitan dengan situasi yang dimainkan.

k) Menarik kesimpulan diskusi.

Pengertian hasil belajar menurut Agus Suprijono (2009: 7), adalah perubahan perilaku secara keseluruhan bukan hanya salah satu aspek potensi kemanusiaan saja”. Sedangkan menurut Slameto (2013: 30), mendefinisikan hasil belajar merupakan tingkat enguasaan yang telah dicapai oleh siswa setelah mengikuti pelajaran dengan tujuan yang telah ditetapkan.

Faktor - faktor yang mempengaruhi keberhasilan belajar, menurut Slameto (2013: 54) ada dua faktor yaitu internal dan eksternal.

* Faktor yang berpengaruh dari dalam diri siswa (Internal) :

1. Faktor Jasmaniah (Cacat tubuh, kesehatan).

2. Faktor Psikologi (Intelegensia, minat, perhatian, bakat, motif, kematangan dan kesiapan).

3. Faktor Kelelahan (Rohani dan Jasmani).

- Faktor yang berpengaruh dari luar diri siswa (Eksternal) :

1. Faktor Keluarga ( cara orang tua mendidik, relasi antar anggota keluarga, suasana rumah, keadaan ekonomi keluarga, pengertian orang tua, latar belakang kebudayaan )

2. Faktor Sekolah ( metode mengajar, kurikulum,mrelasi guru dengan siswa relasi siswa dengan siswa, disiplin sekolah, alat pelajaran, keadaa gedung )

3. Faktor Masyarakat ( kegiatan siswa dalam masyarakat, media masa, teman bergaul, bentuk kehidupan masyarakat )

Berdasarkan teori di atas dan hasil pengamatan tindakan dapat dinyatakan bahwa terjadi peningkatan kualitas pembelajaran, baik proses maupun hasil kemampuan berbicara dengan menggunakan metode bermain peran dari siklus I sampai dengan siklus III. Menurut Santosa, dkk (2005) menyatakan bahwa berbicara asalah mengungkapkan gagasan dan perasaan, menyampaikan sambutan, berdialog, menyampaikan pesan, bertukar pengalaman, menjelaskan, mendeskripsikan dan bermain peran. Berbicara merupakan keterampilan berbahasa yang produktif. Keterampilan ini sebagai implementasi dari hasil simakan. Peristiwa ini berkembang pesat pada kehidupan siswa. Hal ini tampak dari penambahan kosa kata yang disimak siswa dari lingkungan semakin hari semakin bertambah.

Secara garis besar penelitian ini telah berhasil menjawab rumusan masalah yang telah dikemukakan peneliti, yaitu:

a) Siklus Pertama ( I )

Adapun jawaban untuk perumusan masalah di atas adalah: Penelitian tindakan kelas (classroom action research) terhadap peningkatan kemampuan berbicara siswa kelas IV SD Negeri 03 Merigi melalui penerapan metode bermain peran ini dapat meningkatkan keterampilan berbicara siswa. Penelitian ini dilaksanakan dalam tiga siklus, dengan uraian kegiatan sebagai berikut: Sebelum melaksanakan siklus I, peneliti melakukan survei awal untuk mengetahui permasalahan yang terjadi dan kondisi yang ada di lapangan. Peneliti selanjutnya menyusun rencana pembelajaran guna melaksanakan siklus I. Siklus I merupakan tindakan awal untuk mengatasi permasalahanpermasalahan di dalam pembelajaran berbicara. Pada siklus I guru (peneliti) menerapkan bermain peran sebagai metode pembelajaran berbicara dengan berdasar pada kompetensi dasar yang disesuaikan dengan silabus, yaitu"Mengomentari Persoalan Faktual disertai Alasan yang Mendukung 
dengan Memperhatikan Pilihan Kata dan Santun Berbahasa dalam Kegiatan Diskusi".

Peneliti menentukan tema pembelajaran "Memilih Sesuatu yang Menarik". Adapun tugas yang harus dikerjakan siswa pada siklus I ini adalah melakukan kegiatan diskusi secara berkelompok. Tugas tersebut dipraktikkan dengan menggunakan metode bermain peran. Dalam bermain peran kali ini, siswa disuruh untuk memerankan skenario mengenai tugas ketua kelas yang sedang melakukan diskusi bersama dengan beberapa siswa lain mengenai rencana kegiatan liburan sekolah minggu depan. Di setiap kelompok, masingmasing anak berperan sebagai ketua kelas, wakil ketua kelas, dan sisanya sebagai siswa biasa.

Dari pelaksanaan siklus I tersebut, diperoleh deskripsi hasil pembelajaran berbicara yang menyatakan bahwa masih terdapat beberapa kekurangan atau kelemahan di dalam pelaksanaan tindakan. Kekurangan tersebut berasal dari guru, siswa maupun metode yang digunakan. Kelemahan atau kekurangankekurangan dalam pelaksanaan tindakan siklus I ini dapat dikatakan sebagai faktor penyebab rendahnya hasil tes berbicara siswa. Hal tersebut dapat dilihat dari jumlah siswa yang memperoleh nilai di atas 60 (tuntas) hanya 2 siswa atau sekitar $10 \%$ dari jumlah keseluruhan siswa. Selanjutnya kekurangankekurangan tersebut dievaluasi oleh peneliti hingga menghasilkan perencanaan pembelajaran baru, yang diharap mampu mengatasi kekurangan dalam pelaksanaan tindakan siklus I.

b) Siklus Kedua (II)

Siklus II selanjutnya dilaksanakan untuk mengatasi kekurangan/kelemahan yang terjadi selama proses pembelajaran siklus I. Pada siklus II ini guru (peneliti) juga menerapkan bermain peran sebagai metode pembelajaran berbicara dengan berdasar pada kompetensi dasar yang masih sama, yaitu"Mengomentari Persoalan Faktual disertai Alasan yang Mendukung dengan Memperhatikan Pilihan Kata dan Santun Berbahasa dalam Kegiatan Diskusi". Hanya tema pelajarannya saja yang diubah dengan tujuan agar siswa tidak bosan, adapun tema pelajaran di siklus II adalah "Peristiwa". Tugas yang harus dikerjakan siswa pada siklus II masih sama seperti tugas siklus I, yaitu melakukan kegiatan diskusi secara berkelompok (hanya tema yang berubah). Tugas tersebut juga dipraktikkan siswa disuruh untuk memerankan skenario yang berisi tentang pembicaraan kepala desa bersama dengan beberapa warganya mengenai musibah banjir yang sedang melanda daerahnya. Di setiap kelompok, masing-masing anak berperan sebagai kepala desa, ketua RT, dokter, dan sisanya warga desa/korban banjir.

Berdasarkan pelaksanan siklus II terbukti bahwa telah terjadipeningkatan proses dan hasil pembelajaran berbicara dari siklus I. Peningkatan proses dapat dilihat dari meningkatnya minat dan keaktifan siswa dalam mengikuti pembelajaran, sedangkan peningkatan hasil terbukti dari meningkatnya jumlah siswa yang mencapai ketuntasan belajar (mengikuti tes berbicara dalam bentuk diskusi). Pada siklus I siswa yang dinyatakan tuntas dan memiliki kemampuan berbicara dengan baik sejumlah 2 orang, dan pada siklus II terjadi peningkatan menjadi 17 orang. Meskipun terjadi peningkatan kemampuan berbicara yang cukup signifikan pada siklus II, namun masih ditemukan juga beberapa kekurangan/kelemahan didalamnya. Kekurangan dan kelemahan tersebut diantaranya, yaitu guru masih jarang menegur siswa yang gaduh, siswa belum sepenuhnya aktif dalam mengikuti setiap kegiatan pembelajaran, dan masih ada beberapa siswa yang terlihat sulit mengikuti permainan karena malu meskipun mereka tampil secara berkelompok. Selanjutnya peneliti, merancang 
rencana pembelajaran baru untuk siklus selanjutnya, yaitu siklus III yang akan dilaksanakan untuk mengatasi kelemahan/kekurangan yang terjadi pada pelaksanaan tindakan siklus II. Siklus III merupakan perencanaan siklus terakhir dalam tindakan penelitian ini, sehingga pada siklus ini guru berusaha memperkecil segala kelemahan yang terjadi.

c) Siklus Ketiga ( III)

Pada siklus III ini guru (peneliti) juga menerapkan bermain peran sebagai metode pembelajaran berbicara, namun kompetensi dasar yang dijadikan pedoman berbeda dengan kompetensi dasar pembelajaran berbicara di kedua siklus sebelumnya, yaitu" Memerankan Tokoh Drama dengan Lafal, Intonasi, dan Ekspresi yang Tepat". Alasan guru mengganti kompetensi dasar tersebut adalah agar siswa tidak merasa bosan melakukan praktik berbicara dalam bentuk diskusi yang telah dilakukan dalam siklus I dan II. Meskipun ada perubahan kompetensi dasar yang digunakan, namun dasar pembelajaran tetap bertumpu pada standar kompetensi yang sama, yaitu "Mengungkapkan Pikiran dan Perasaan Secara Lisan dalam Diskusi dan Bermain Drama". Tema pelajaran di siklus III yaitu "Kesehatan". Berbeda dengan pelaksanaan kedua siklus sebelumnya, dalam siklus III ini tugas yang harus dikerjakan siswa, yaitu melakukan kegiatan bermain drama (sesuai dengan kompetensi dasar) yang juga dipraktikkan dengan menggunakan metode bermain peran. Adapun skenario yang akan diperankan oleh kelima kelompok adalah sama, yaitu memerankan suatu kejadian tentang akibat yang diterima seorang anak karena suka jajan sembarangan.

Dari pelaksanaan siklus III terbukti bahwa telah terjadi peningkatan proses dan hasil pembelajaran berbicara dari siklus II. Peningkatan proses dapat dilihat dari meningkatnya minat dan keaktifan keseluruhan siswa, sedangkan peningkatan hasil terbukti dari meningkatnya jumlah siswa yang mencapai ketuntasan belajar dari 17 menjadi 20 orang.

\section{Kesimpulan}

1. Penerapan metode bermain peran dapat meningkatkan kualitas proses pembelajaran keterampilan berbicara. Hal ini ditandai dengan persentase minat,keaktifan, serta nilai rata-rata proses pembelajaran siswa mengalami peningkatan dalam tiap siklusnya. Pada siklus I, rata-rata nilai proses pembelajaran berbicara siswa sebesar 41.35; Pada siklus II sebesar 62.65; dan pada siklus III sebesar 76.50. Di samping itu, siswa juga terlihat lebih rileks di dalam mengikuti proses pembelajaran, hal ini disebabkan karena situasi pembelajaran yang diciptakan melalui penerapan metode bermain peran hampir sama dengan situasi bermain. Jadi siswa merasa lebih nyaman dan mudah dalam menginterpretasikan tugas mereka.

2. Penerapan metode bermain peran dapat meningkatkan keterampilan berbicara siswa. Hal ini ditandai dengan nilai rata-rata keterampilan berbicara siswa yang mengalami peningkatan pada tiap siklusnya, yaitu siklus I sebesar 41.35; siklus II sebesar 62.65; dan siklus III sebesar 76.50 Dengan demikian dapat dikatakan bahwa kualitas hasil pembelajaran berbicara siswa kelas IV SD Negeri 03 Merigi telah meningkat. Terbukti dari 20 jumlah siswa, semuanya telah mengalami ketuntasan belajar dengan mendapatkan nilai di atas 60 (standarketuntasan).

\section{Saran}

1. Siswa seharusnya memahami bahwa keterampilan berbicara merupakan hal penting yang harus dikuasai, untuk itu siswa perlu mengikuti pembelajaran 
berbicara dengan penuh kesungguhan agar siswa memiliki keterampilan berbicara yang baik. Siswa diharapkan dapat bekerja sama dengan baik jika guru menghendaki mereka untuk melaksanakan tugas secara berkelompok.

2. Guru hendaknya menerapkan metode bermain peran dalam kegiatan belajar mengajar khususnya pada pengajaran berbicara, karena metode bermain peran lebih efektif dibandingkan dengan metode konvensional yang pada umumnya masih sering digunakan dalam pembelajaran berbicara. Pihak sekolah hendaknya menyediakan fasilitas yang memadai bagi para guru untuk dapat menerapkan metode bermain peran dalam kegiatan belajar mengajar di kelas.

3. Mengingat metode bermain peran dapat meningkatkan kualitas proses dan hasil pembelajaran berbicara, maka untuk kelas dengan karakteristik yang relatif sama dapat menerapkan metode serupa untuk meningkatkan kualitas pembelajarannya.

\section{Referensi}

Suprijono, A. 2014. Cooperative Learning Teori dan Paikem. Yogyakarta: Pustaka Belajar

Arief S., Sadiman, R., Rahardjo, A. H dan Rahardjito. 2008. Media Pendidikan. Jakarta: PT Raja Grafindo Persada.

Burhan, N. 2001. Penilaian dalam Pengajaran Bahasa dan Sastra, edisi ketiga. Yogyakarta: BPFE.

Darmiyati, Z dan Budiasih. 2001. Pendidikan Bahasa dan Sastra Indonesia di Kelas Rendah. Yogyakarta: PAS.

Departemen Pendidikan Nasional. 2006. Kurikulum Standar Isi: Mata Pelajaran Bahasa Indonesia Untuk SD/MI. Jakarta: Diknas.

Dimyati dan Mudjiono. 1999. Belajar dan Pembelajaran. Jakarta: Rineka Cipta.

Gorys, K. 2001. Komposisi: Sebuah Pengantar Kemahiran Berbahasa, cetakan XII. Ende: Nusa Indah.

Hamdani. 2011. Strategi Belajar Mengajar. Bandung: CV. Pustaka Setia.

Henry, G. T. 1985. Berbicara: Sebagai Suatu Keterampilan Berbahasa. Bandung: Angkasa.

Herman, J. Dan Waluyo. 2002. Drama: Teori dan Pengajarannya. Yogyakarta: Hanindita Graha Widya.

Iswandi. (2012). Peningkatan Aktivitas dan Hasil Belajar Pembelajaran PKn dengan Bermain Peran Kelas IV SDN 09. http://jurnal.untan.ac.id/index.

Maidar G. A. dan Mukti U.S. 1991. Kemampuan Berbicara Bahasa Indonesia. Jakarta: Erlangga

Miftahul, H. (2014). Model - model Pengajaran dan Pembelajaran. Yogyakarta: Pustaka Pelajar. 
Miles, M. B. dan Huberman, A. M. 1992. Analisis Data Kualitatif (Diterjemahkan Tjetjep Rohendi Rohidi). Jakarta: UI Press.

Oemar, H. (2009). Perencanaan Pengajaran Berdasarkan Pendekatan Sistem. Jakarta: PT. Bumi Aksara.

Oemar, H. (2001). Kurikulum dan Pembelajaran. Jakarta: Bumi Aksara. . 2003. Perencanaan Pengajaran Berdasarkan Pendekatan Sistem. Jakarta: Bumi Aksara.

Roestiyah N.K. 2001. Strategi Belajar Mengajar. Jakarta: Rineka Cipta.

Rochiati, W. 2007. Metode Penelitian Tindakan Kelas. Bandung: PT Remaja Rosdakarya.

Santosa. 2005. Materi dan Pembelajaran Bahasa Indonesia SD. Jakarta: UT.

Santrock, J.W. (2012). Perkembangan Masa Hidup. (Terjemahan Benedictine Widyasinta). Newyork: McGraw-Hill Companies.

Silberman, M. L., 2006. Active Learning: 101 Cara Belajar Siswa Aktif (Diterjemahkan Raisul Muttaqien). Bandung: Nusamedia.

Slameto. (2013). BelajardanFaktor - factor yang Mempengaruhinya. Jakarta: RenikaCipta.

Solchan, dkk.2009. Pendidikan Bahasa Indonesia di SD. Universitas Terbuka.

Sri, U. S. N. 1993. Metodologi Pengajaran Bahasa. Jakarta: Gramedia Pustaka Utama

Arikunto, S., dan Suhardjono, S. 2007. Penelitian Tindakan Kelas. Jakarta: Bumi Aksara.

Sumiati, A. 2009. Metode Pembelajaran. Bandung: CV. Wacana Prima

Supriyadi. 2005. Upaya Meningkatkan Keterampilan Berbicara Siswa Kelas Rendah Sekolah Dasar Dalam Lingua: Jurnal Bahasa dan Sastra. 